\title{
THE EFFECT OT SELECTED FACTORS ON THE PROCESS OF WEAR UNDER OSCILLATORY MOTION
}

\author{
WPLYW WYBRANYCH CZYNNIKÓW NA PROCES ZUŻYCIA \\ W RUCHU OSCYLACYJNYM
}

\begin{abstract}
Key words:
wear testing, volume loss, oscillatory motion.

Abstract

On the surface of the components cooperating under the sliding motion, complex tribological wear processes take place. It leads to the volume loss of components of the friction pair direct metal to metal contact. The amount of this volume depends on the input factors that determine the operation of the friction couple. Therefore, the aim on the presented work was to evaluate the influence of the selected factors on the volume loss on the block and ring under the oscillatory motion. Wear tests were carried out in a non-conformal contact with the use of the T- 05 tribotester with the assumed number of operated cycles. As the part of the tests, measurements of the volume loss of the test elements were made. The geometrical structure of the surface of the block and counter block was formed on the basis selected technological process. The relationship between volume and the following factors was obtained: load, frequency of oscillation, and amplitude of oscillation.

Słowa kluczowe: Streszczenie

badania zużyciowe, ubytek objętościowy, ruch oscylacyjny.

Na powierzchni elementów współpracujących w ruchu ślizgowym zachodzą złożone procesy zużywania tribologicznego, które podczas bezpośredniego kontaktu metal-metal doprowadzają do powstania ubytku objętościowego tych elementów. Wielkość tego zużycia jest zależna od czynników wejściowych warunkujących współpracę pary trącej. W związku z tym w pracy przyjęto za cel wyznaczenie wpływu wybranych czynników na ubytek objętościowy próbki i przeciwpróbki w ruchu oscylacyjnym. Badania zużyciowe zrealizowano w styku niekonforemnym dla skojarzenia rolka-klocek na testerze T-05 przy założonej liczbie cykli pracy. W ramach badań wykonano pomiary ubytku objętościowego elementów testowych. Strukturę geometryczną powierzchni próbki i przeciwpróbki ukształtowano w oparciu o wybrany proces technologiczny. Uzyskano zależność między ubytkiem objętościowym a następującymi czynnikami: siła nacisku, częstotliwość oscylacji, amplituda oscylacji.
\end{abstract}

\section{INTRODUCTION}

Nowadays, the operation and maintenance of machines are a serious problem from the scientific, technical, and economic point of view. It is due to the increasing requirements of customers. Many operational factors, such as applied load, pressure, and relative speed are higher and higher. It leads to the development of complex wear phenomena that change the mechanical properties of the contact surface. It results in revealing defects during operation because of incorrect selection and the implementation of the friction couple affecting the durability of the machines and their components.
To avoid failure, mechanical components are often overdesigned. It is worth mentioning that the proper shaping of the wear parameters takes place at the design stage of life cycle of mechanical machines. Application of adequate materials is undertaken at the construction stage; whereas, the quality of production is influenced at the technological stage. It follows that preventing the excursive wear of the machine components in their future operation is possible at each of the mentioned stages. More and more attention is paid to the study of the influence of operational factors on wear in sliding motion $[\mathbf{L . ~ 3 , ~ 8 , ~ 1 0 ] . ~}$

\footnotetext{
Cracow University of Technology, Faculty of Mechanical Engineering, Jana Pawla II 37, 31-864 Cracow, Poland, e-mail: gkaczor@pk.edu.pl.
} 
The authors of work [L. 6] investigated the effect on the normal load and coating morphology on the tribological behaviour. They used a Zn-Ni coating as a replacement of $\mathrm{Cd}$ coating in the aerospace industry. The wear volume and the wear rate were obtained under given conditions to assess the usefulness of the selected coatings. It turned out that coating morphology has a great influence on the wear as a result of the interaction of many wear mechanisms at the same time.

To determine the influence of selected factors on the studied phenomenon, the researchers often use different methods concerned with the design of an experiment. One of the most popular methods is the Taguchi method. For example, it was used in the paper [L. 5] to optimize the machining parameters for minimum surface roughness and flank wear in the milling Hadfields steel. In the paper, the analysis of variance was also used to determine the effects of the machining parameters on the surface roughness and flank wear.

Despite the fact that the impact of surface roughness on the friction characteristics is considered by many researchers in their works, the effects of roughness on different types of wear still remains unclear. It was the reason for developing a methodology to take into account the roughness effect in fretting wear simulations [L. 9]. The authors confirmed that roughness has an insignificant effect on the wear characteristics under sliding conditions.

Other factors that affect the wear are normal load, amplitude, and frequency. Works [L. 2, 11] investigated the influence of amplitude and oscillation on the wear mode and wear coefficient under given conditions. It was observed that the change in the wear mode corresponding to wear coefficient depends on amplitude rather than frequency. If sliding amplitude increases, the wear amount and the scar size increase. Wear mode changed from stick to gross slip and sliding. In the case of normal load, it was found that its influence is not always meaningful.

An important issue is the type of the movement between the components of the friction couple, as it was presented in the work [L. 1]. The authors indicated that the required number of cycles under reciprocating sliding motion at the point of scuffing is much greater than the same number of cycles under unidirectional sliding motion. In the reciprocating and oscillatory motion, the relative speed of sliding at the point where there is a change in the direction of the movement is equal to 0 . It is conductive to the development of many types of wear phenomena simultaneously.

The following paper presents the results of the research conducted under oscillatory motion. It concerns the study of the impact of selected factors on the volume loss taking into account a selected structure of the surface and with the use of the Taguchi method and analysis of variance (ANOVA).

\section{METHODS OF ANALYSIS}

The main tests were preceded by performing the preliminary tests to determine the range of the input parameters: load, amplitude of oscillation, and frequency of oscillation. To establish the plan of the main tests, the Taguchi method was used. Application of this method allows one to determine the influence of selected parameters on the volume loss. To do this, Taguchi uses a signal-to-noise factor. Depending on whether the maximum, minimum, or nominal output value will be taken into account, referring to the greatest impact of the given control factor on the tests results, there are three dependencies used to determine the $\mathrm{S} / \mathrm{N}$ ratio [L. 7]:

- Maximum-the-best, $S / \mathrm{N}=-10 \log \left[\frac{\sum\left(1 / \mathrm{x}^{2}\right)}{\mathrm{n}}\right]$

- Minimum-the-best, $\mathrm{S} / \mathrm{N}=-\log \left[\frac{\sum \mathrm{x}^{2}}{\mathrm{n}}\right]$

- Nominal-the-best, $\mathrm{S} / \mathrm{N}=-10 \log \left[\widehat{\sigma}^{2}\right]$

where

$\mathrm{x}$ - responses of the given factor,

$\mathrm{n}$ - number of responses in the factor level combination,

$\widehat{\sigma}$ - standard deviation.

In the conducted research, maximum-the-best criterion was selected, because the biggest difference in the values of $\mathrm{S} / \mathrm{N}$ ratio would indicate the greatest impact of a given factor on the studied phenomenon.

Due to the complex effects of various factors on the measured volume loss, there may be significant differences between the measured values. It is related to the variability of observation (difference between the mean and any value in a given group) and the variability between groups (cause by different levels of the studied factors). Therefore, it is helpful to understand the significance of the influence of the type and value of particular factors on the results of the study. This analysis is called ANOVA (analysis of variance), and it begins by assuming the null hypothesis, which means there is no difference in mean values of a measured magnitude. At first, the sum of squares total should be obtained from the following equation:

$$
\operatorname{SST}=\sum_{\mathrm{j}=1}^{\mathrm{c}} \sum_{\mathrm{i}=1}^{\mathrm{n}_{\mathrm{i}}}\left(\mathrm{x}_{\mathrm{ij}}-\overline{\overline{\mathrm{x}}}\right)^{2}
$$

where

$\mathrm{x}_{\mathrm{ij}}$ - the value of the $\mathrm{i}$ measurement for the $\mathrm{j}$ group,

$\overline{\bar{x}}=\frac{1}{n} \sum_{i=1}^{c} \sum_{j=1}^{n_{i}} x_{i j}-$ global mean.

The sum of squares total consists in the sum of squares between (SSB) and the sum of squares within, as follows:

$$
\operatorname{SSB}=\sum_{\mathrm{j}=1}^{\mathrm{c}} \mathrm{n}_{\mathrm{j}}\left(\overline{\mathrm{x}_{\mathrm{j}}}-\overline{\overline{\mathrm{x}}}\right)^{2}
$$




$$
\operatorname{SSW}=\sum_{\mathrm{j}=1}^{\mathrm{c}} \sum_{\mathrm{i}=1}^{\mathrm{n}_{\mathrm{j}}}\left(\mathrm{x}_{\mathrm{ij}}-\overline{\mathrm{x}}_{\mathrm{j}}\right)^{2}
$$

The fundamental equation of the ANOVA method is given as

$$
\mathrm{SST}=\mathrm{SSB}+\mathrm{SSW}
$$

For individual SSB and SSW, there are two types of variance, as given below:

- The mean of squares between

$$
\operatorname{MSB}=\frac{\mathrm{SSB}}{\mathrm{df}_{\mathrm{B}}}
$$

where

$d f_{B}=(c-1)$ is the number of degrees of freedom related to the set of $\mathrm{c}$ group, associated with MSB; and,

- The mean of squares within

$$
\mathrm{MSW}=\frac{\mathrm{sSW}}{\mathrm{df}_{\mathrm{W}}}
$$

where

$d f_{W}=(\mathrm{c}-1)$ is the number of degrees of freedom related to the set of $\mathrm{c}$ group, associated with MSW.

The total number of the degree of freedom is obtained as follows:

$$
d f=d f_{B}+d f_{W}
$$

a)
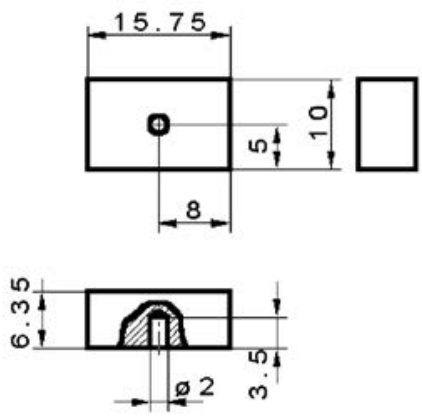

Fig. 1. The dimensions of: a) block, b) ring [L. 12]

Rys. 1. Wymiary: a) klocka, b) rolki [L. 12]

Figures 2a-2b present images of the surface for the selected block and ring, obtained with the use of an Epiquant optical microscope before the tests.

The geometric structure of the surface of the example block and ring before the wear tests is presented in Figures 3a-3b.

The mass of the block and the ring was measured before and after the wear tests. On this basis, the volume
The next step is to calculate the statistic ratio of Fisher-Snedecor, as given below:

$$
\mathrm{F}=\frac{\mathrm{MSB}}{\mathrm{MSW}}
$$

The obtained value from the Fisher-Snedecor equation is then compared with the critical p-value, read from the tables related to the Fisher-Snedecor distribution at the significance level of $\rho$. If there is the following relation:

$$
\mathrm{F}>\mathrm{p}
$$

we reject the null hypothesis. With regard to the wear tests, this means that the change in the value of a given factor in the assumed range has a significant impact on the volume loss. In the case of the opposite dependence, there is no reason to reject the hypothesis established.

\section{EXPERIMENTAL DETAILS}

Prior to the main research, numerous preliminary tests were carried out with the use of block-on-ring test machine under oscillatory motion. Steel type S235 was chosen as commonly used material for machine construction. The test were carried out in the laboratory of the Institute of Rail Vehicles at an ambient temperature of approx. $20^{\circ} \mathrm{C}$, under assumed number of the working cycles of 10000 . To eliminate the influence of external factors, the tests were conducted under non-lubricated conditions. The block and ring were made according to the specification, as shown in the Fig. 1.

b)

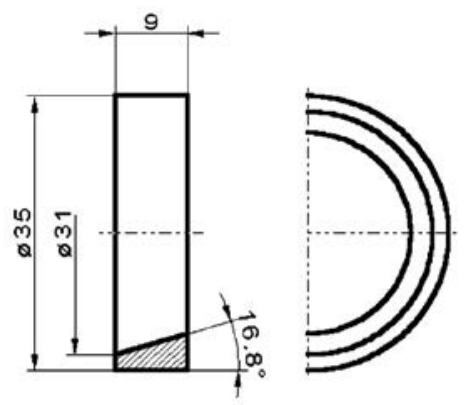

loss was determined. Based on the preliminary tests, a set of the controlled factors was assumed for the main research. It includes load, amplitude of oscillation, and frequency of oscillation. The presented research takes into account 3 levels of each factor. The L9 orthogonal array related to the Taguchi method is presented in the Table 1. 


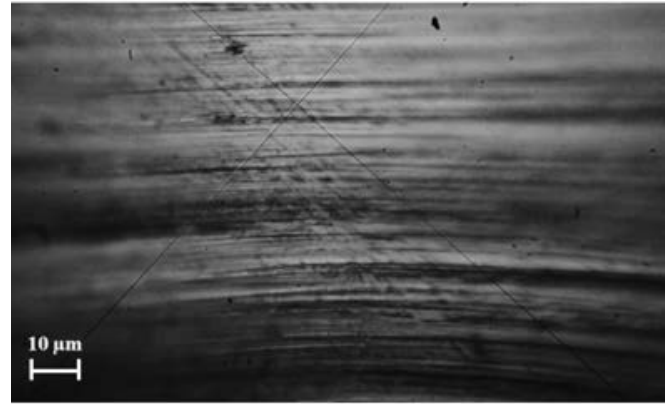

Fig. 2a. Optical image of the surface of an example block before the wear tests

Rys. 2a. Obraz powierzchni przykładowego klocka przed badaniami zużyciowymi

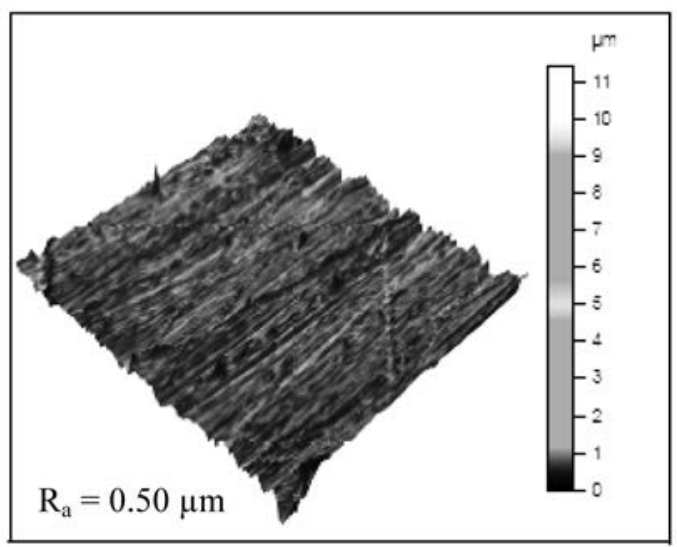

Fig. 3a. Geometric structure of surface of the example block

Rys. 3a. Struktura geometryczna powierzchni przykładowego klocka

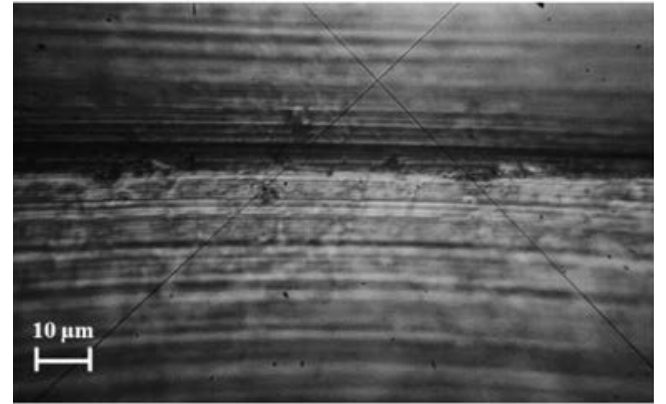

Fig. 2b. Optical image of the surface of an example ring before the wear tests

Rys. 2b. Obraz powierzchni przykładowej rolki przed badaniami zużyciowymi

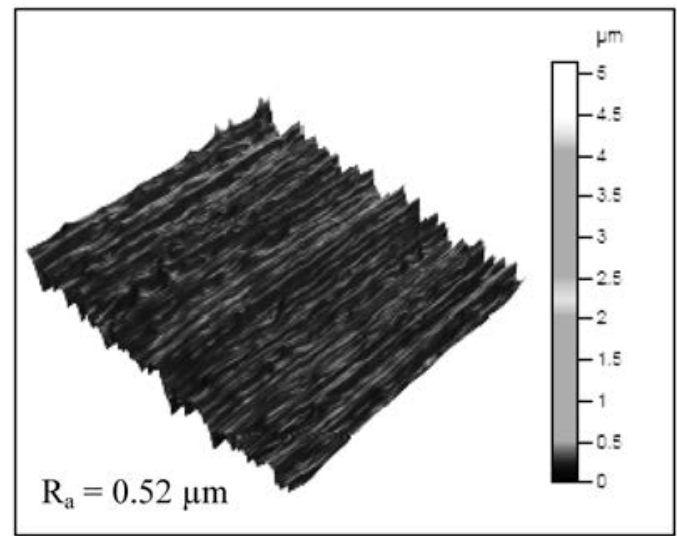

Fig. 3b. Geometric structure of surface of the example ring

Rys. 3b. Struktura geometryczna powierzchni przykładowej rolki

Table 1. A set of the controlled factors for the wear tests

Tabela 1. Zbiór czynników kontrolowanych w badaniach zużyciowych

\begin{tabular}{|c|c|c|c|}
\hline \multirow{2}{*}{ No. } & \multicolumn{3}{|c|}{ Controlled factor } \\
\cline { 2 - 4 } & $\begin{array}{c}\text { Load } \\
\mathbf{P}[\mathbf{N}]\end{array}$ & $\begin{array}{c}\text { Amplitude of oscillation } \boldsymbol{\alpha} \\
{\left[{ }^{\circ}\right]}\end{array}$ & $\begin{array}{c}\text { Frequency of oscillation f } \\
{[\mathbf{H z}]}\end{array}$ \\
\hline 1 & 0.33 & 10 & 1 \\
\hline 2 & 0.33 & 20 & 2 \\
\hline 3 & 0.33 & 30 & 3.5 \\
\hline 4 & 0.55 & 10 & 2 \\
\hline 5 & 0.55 & 20 & 3.5 \\
\hline 6 & 0.55 & 30 & 3.5 \\
\hline 7 & 0.78 & 10 & 1 \\
\hline 8 & 0.78 & 20 & 2 \\
\hline 9 & 0.78 & 30 & \\
\hline
\end{tabular}




\section{RESULTS AND DISCUSSION}

Table 2 shows the results of the wear tests related to the volume loss of block and ring, obtained according to the assumed Taguchi plan.

In order to evaluate the influence of the selected factors on the volume loss of the block and ring under the oscillatory motion and non-lubricated conditions, the $\mathrm{S} / \mathrm{N}$ ratio was calculated. The criterion maximumthe-best was chosen, as well as the significance level of $\rho=0.05$. It was assumed that the bigger the difference between the highest and the lowest value of the $\mathrm{S} / \mathrm{N}$ ratio, the greater the impact on the volume loss. The results of the analysis are shown in Table 3.

Table 2. The results of the volume loss for the tested friction couple

Tabela 2. Wyniki badania zużycia objętościowego dla testowej pary ciernej

\begin{tabular}{|c|c|c|c|c|c|c|c|c|c|}
\hline \multirow{2}{*}{$\begin{array}{l}\text { Test } \\
\text { order }\end{array}$} & \multirow{2}{*}{$\begin{array}{l}\text { Load } \\
P[N]\end{array}$} & \multirow{2}{*}{$\begin{array}{c}\text { Amplitude } \\
\text { of oscillation } \\
\alpha\left[^{\circ}\right]\end{array}$} & \multirow{2}{*}{$\begin{array}{c}\text { Frequency } \\
\text { of oscillation } \\
\text { f }[\mathrm{Hz}]\end{array}$} & \multicolumn{2}{|c|}{$\begin{array}{c}\text { Mass of block } \\
\mathbf{m}_{\mathrm{p}}[\mathrm{g}]\end{array}$} & \multicolumn{2}{|c|}{$\begin{array}{c}\text { Mass of ring } \\
m_{p p}[g]\end{array}$} & \multirow{2}{*}{$\begin{array}{c}\text { Volume loss } \\
\text { of block Lp } \\
{\left[\mathrm{mm}^{3}\right]}\end{array}$} & \multirow{2}{*}{$\begin{array}{l}\text { Volume loss } \\
\text { of ring Lpp } \\
\quad\left[\mathrm{mm}^{3}\right]\end{array}$} \\
\hline & & & & $\begin{array}{c}\text { before } \\
\text { test }\end{array}$ & $\begin{array}{c}\text { after } \\
\text { test }\end{array}$ & $\begin{array}{c}\text { before } \\
\text { test }\end{array}$ & $\begin{array}{c}\text { after } \\
\text { test }\end{array}$ & & \\
\hline S1 & 0.32 & 10 & 1 & 7.738 & 7.715 & 21.944 & 21.916 & 2.949 & 3.590 \\
\hline S2 & 0.32 & 20 & 2 & 7.786 & 7.743 & 21.986 & 21.943 & 5.513 & 5.513 \\
\hline S3 & 0.32 & 30 & 3.5 & 7.806 & 7.739 & 22.083 & 22.024 & 8.590 & 7.564 \\
\hline S4 & 0.55 & 10 & 2 & 7.790 & 7.760 & 21.916 & 21.883 & 3.846 & 4.231 \\
\hline S5 & 0.55 & 20 & 3.5 & 7.788 & 7.723 & 22.108 & 22.050 & 8.333 & 7.436 \\
\hline S6 & 0.55 & 30 & 1 & 7.739 & 7.697 & 22.024 & 21.980 & 5.385 & 5.641 \\
\hline S7 & 0.78 & 10 & 3.5 & 7.760 & 7.731 & 21.866 & 21.841 & 3.718 & 3.205 \\
\hline S8 & 0.78 & 20 & 1 & 7.716 & 7.653 & 22.021 & 21.832 & 8.077 & 9.231 \\
\hline S9 & 0.78 & 30 & 2 & 7.795 & 7.721 & 21.980 & 21.890 & 9.487 & 11.538 \\
\hline
\end{tabular}

Table 3. Values of $\mathrm{S} / \mathrm{N}$ ratio for block

Tabela 3. Wartości wskaźnika S/N dla klocka

\begin{tabular}{|c|c|c|c|}
\hline Level & P & $\boldsymbol{\alpha}$ & $\mathbf{f}$ \\
\hline 1 & 14.300 & 10.830 & 14.050 \\
\hline 2 & 14.910 & 17.130 & 15.360 \\
\hline 3 & 16.360 & 17.620 & 2.170 \\
\hline Delta & 2.060 & 6.780 & 2 \\
\hline Rank & 3 & 1 & \\
\hline
\end{tabular}

Table 4. Values of $\mathbf{S} / \mathbf{N}$ ratio for ring

Tabela 4. Wartości wskaźnika $\mathrm{S} / \mathrm{N}$ dla rolki

\begin{tabular}{|c|c|c|c|}
\hline Level & $\mathbf{P}$ & $\boldsymbol{\alpha}$ & $\mathbf{f}$ \\
\hline 1 & 14.500 & 11.250 & 15.140 \\
\hline 2 & 14.990 & 17.190 & 16.200 \\
\hline 3 & 16.890 & 17.950 & 15.040 \\
\hline Delta & 2.390 & 6.700 & 1.160 \\
\hline Rank & 2 & 1 & 3 \\
\hline
\end{tabular}

The results presented in Tables $\mathbf{2}$ and $\mathbf{3}$ indicate that the amplitude of oscillation has the greatest influence on the volume loss both for the block and the ring. To assess whether the change in the value of the tested parameters in the assumed range has a significant effect on the change in the volume loss of the friction couple, an analysis of variance based on the methodology presented in the previous section was performed. The results of these analyses are shown in Tables 4 and 5: 
Table 5. Results from an ANOVA analysis for block

Tabela 5. Wyniki analizy wariancji dla klocka

\begin{tabular}{|c|c|c|c|c|c|c|c|c|}
\hline Factor & SSB & df $_{\mathbf{B}}$ & MSB & SSW & $\mathbf{d f}_{\mathbf{W}}$ & MSW & F & $\mathbf{p}$ \\
\hline $\mathrm{P}$ & 3.553 & 2 & 1.777 & 44.442 & 6 & 7.407 & 0.240 & 0.794 \\
\hline$\alpha$ & 33.36 & 2 & 16.680 & 14.65 & 6 & 2.439 & 6.840 & 0.028 \\
\hline $\mathrm{f}$ & 3.005 & 2 & 1.502 & 44.990 & 6 & 7.498 & 0.200 & 0.824 \\
\hline
\end{tabular}

Table 6. Results from an ANOVA analysis for ring

Tabela 6. Wyniki analizy wariancji dla rolki

\begin{tabular}{|c|c|c|c|c|c|c|c|c|}
\hline Factor & SSB & $\mathbf{d f}_{\mathbf{B}}$ & MSB & SSW & $\mathbf{d f}_{\mathbf{w}}$ & $\mathbf{M S W}$ & $\mathbf{F}$ & $\mathbf{p}$ \\
\hline $\mathrm{P}$ & 10.920 & 2 & 5.458 & 50.080 & 6 & 8.347 & 0.650 & 0.554 \\
\hline$\alpha$ & 35.460 & 2 & 17.730 & 25.540 & 6 & 4.257 & 4.170 & 0.073 \\
\hline $\mathrm{f}$ & 1.943 & 2 & 0.972 & 59.057 & 6 & 9.843 & 0.010 & 0.907 \\
\hline
\end{tabular}

The calculated value of Fisher-Snedecor statistic test was compared with the critical value of $p$, which was read from the Fisher-Snedecor distribution tables for the adopted level of significance. As shown in Table 4, in the case of the block, the value of FisherSnedecor statistic is less than the critical value $\mathrm{p}$ for the factors of applied load and frequency of oscillation. Therefore, for these factors, there is no reason to reject the null hypothesis. From the statistical point of view, this means that the change in the value of these factors does not significantly affect the average volume loss of block. With reference to the ring, the null hypothesis is rejected for factors such as pressure force and amplitude of oscillation.

Charts of the effect of the studied factors on the mean volume loss of block and ring are presented in Figs. 2, 3, 4 .

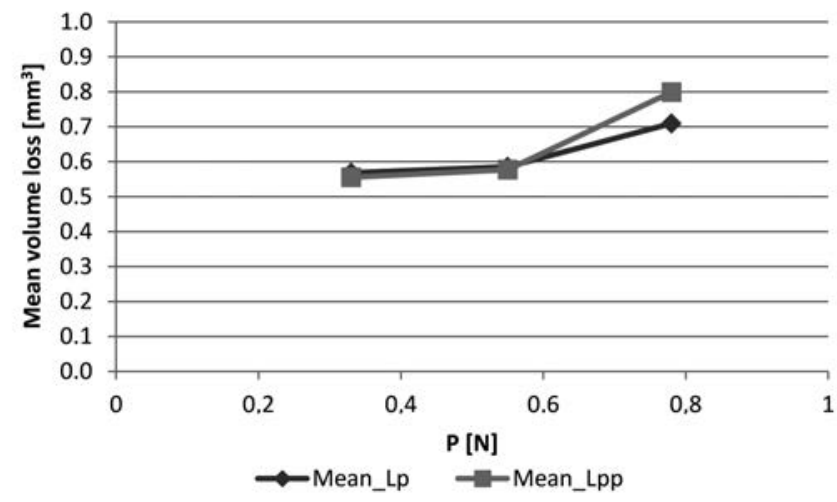

Fig. 4. The effect of the load on the mean volume loss of block (Mean_Lp) and ring (Mean_Lpp)

Rys. 4. Wpływ obciążenia na średnie zużycie objętościowe klocka (Mean_Lp) i rolki (Mean_Lpp)

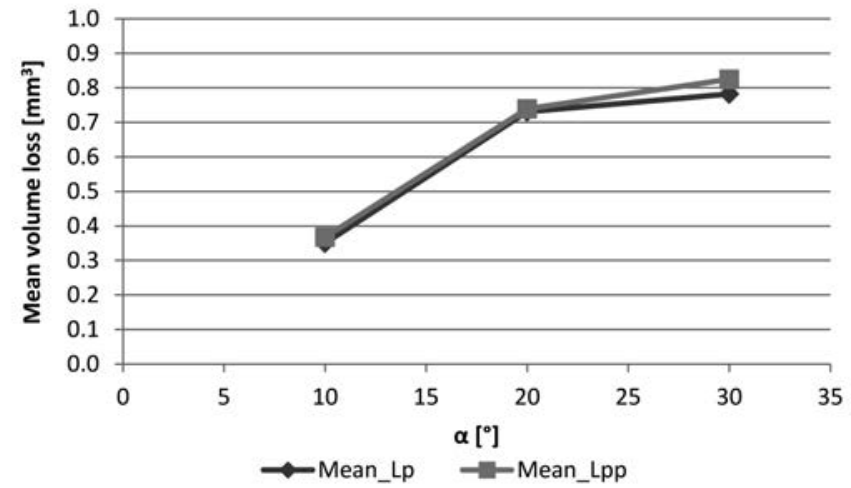

Fig. 5. The effect of the amplitude of oscillation on the mean volume loss of block (Mean_Lp) and ring (Mean_Lpp)

Rys. 5. Wpływ amplitudy oscylacji na średnie zużycie objętościowe klocka (Mean_Lp) i rolki (Mean_Lpp) 


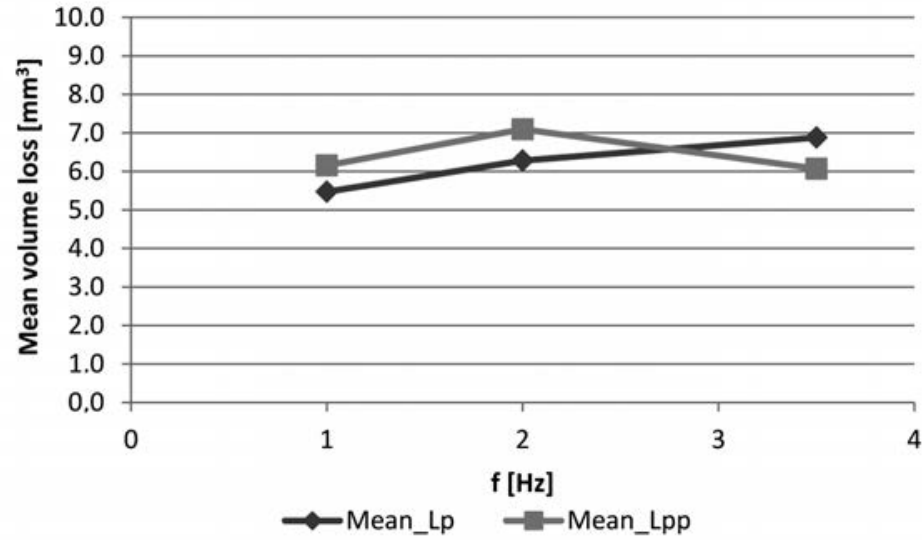

Fig. 6. The effect of the frequency of oscillation on the mean volume loss of block (Mean_Lp) and ring (Mean_Lpp) Rys. 6. Wpływ częstotliwości oscylacji na średnie zużycie objętościowe klocka (Mean_Lp) i rolki (Mean_Lpp)

On the basis of Figures 4-6, one can conclude that the higher load and the amplitude of oscillation, the greater is the mean volume loss of block and ring. The impact of the frequency of oscillation has a slight increasing tendency for the block, while, for the ring,

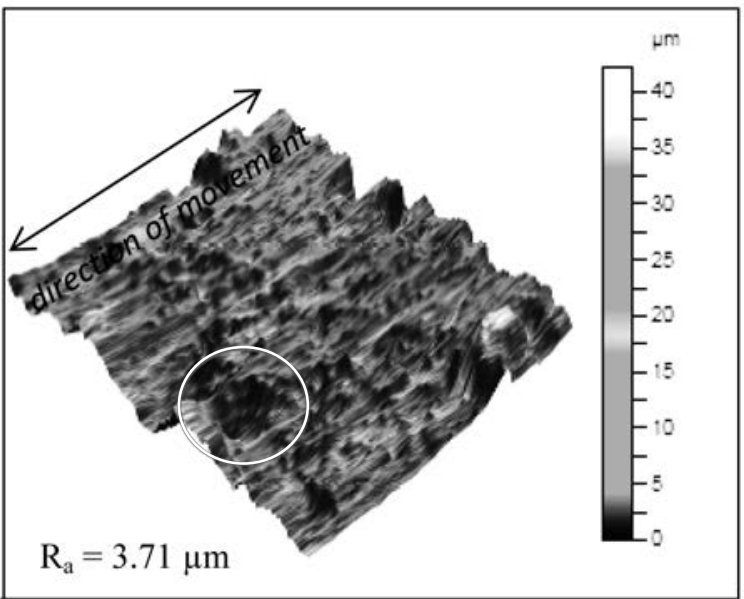

Fig. 7a. Geometric structure of surface of the example block

Rys. 7a. Struktura geometryczna powierzchni przykładowego klocka po badaniach zużyciowych

Figures $7 \mathbf{a}$ and $\mathbf{7 b}$ show the scars of wear on the geometric surface of the example block and ring after the conducted tests. The largest change in the roughness of the surface occurred with reference to the ring. Damage to this surface can be noticed, as a result of the simultaneous effect of complex phenomena that lead to the loss of volume of the surface. As we know from the literature, elementary processes of tribological wear, such as abrasive wear and adhesive wear, may occur in the asperity contact areas. They may cause extensive cavities, as marked by the red circles this trend increases in the range from 1 to $2 \mathrm{~Hz}$, and it decreases in the range from 2 to $3 \mathrm{~Hz}$.

The geometric structure of the surface of the example block and ring after the wear tests is presented in Figures 3a-3b.

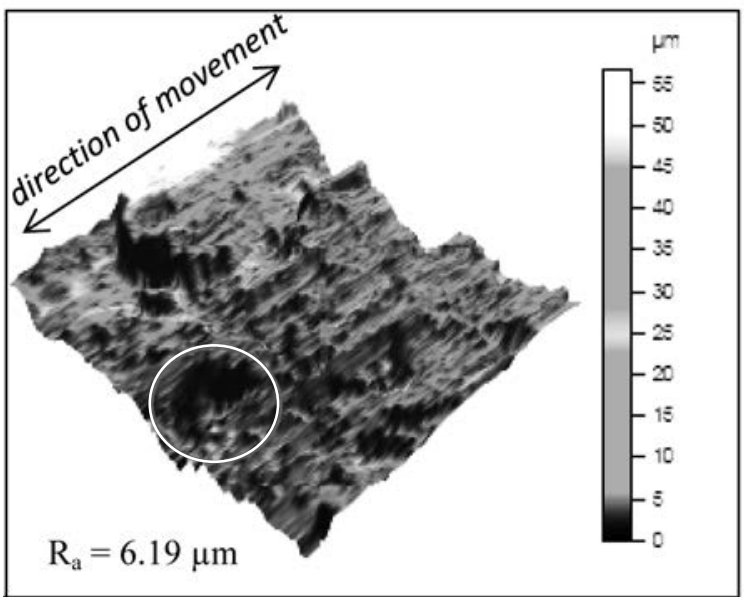

Fig. 7b. Geometric structure of surface of the example ring

Rys. 7b. Struktura geometryczna powierzchni przykładowej rolki po badaniach zużyciowych

$[$ L. 1, 4]. The association of the above facts may be the basis for further research.

\section{CONCLUSIONS}

The presented work investigates the influence of selected factors on the volume loss of the components of a given friction couple, operating in oscillatory motion. The Taguchi method was used to determine the impact of these factors on the amount of wear, and the ANOVA 
method was applied to evaluate the significance of this impact. The geometric structure of the surface for the selected block and ring were measured before and after the wear tests. On the surface of the friction couple in the area of wear after these tests, extensive damage can be observed, which affect the change of the surface structure. The technological structure becomes the operating one. The presented approach can be used in the designing phase of real components of machines to predict the critical values of selected operating factors that should not be exceeded. It is particularly important for reducing the wear when mixed or no lubricated conditions occurs.

\section{REFERENCES}

1. Cho D.H., Lee Y.Z.: Comparison of scuffing life between unidirectional and reciprocating sliding motion. Wear 271(2011), pp. 1637-1641.

2. Chung I., Lee M.: An experimental study on fretting wear behaviour of cross-contacting Inconel 690 tubes. Nuclear Engineering and Design 241(2011), pp. 4103-4110.

3. Hebda M., Procesy tarcia, smarowania i zużycia maszyn. Instytut Technologii Eksploatacji - PIB, Warszawa, 2007.

4. Kaczor G.: Scuffing tendencies under the oscillatory motion. Doctoral thesis. Cracow University of Technology, Kraków 2018.

5. Kivak T.: Optimization of surface roughness and flank wear using the Taguchi method in milling of Hadfield steel with PVD and CVD coated inserts. Measurement 50 (2014), pp. 19-28.

6. Lee L., Behera P., Sriraman K.R., Chromik R.R.: The effect of contact stress on the sliding wear behaviour of Zn-Ni electrodeposited coatings. Wear 400-401(2018), pp. 82-92.

7. Mercik J., Szmigiel C.: Ekonometria. Oficyna Wydawnicza Politechniki Wrocławskiej. Wrocław 2007.

8. Michalczewski R.: Właściwości tribologiczne smarowanych wysokoobciążonych elementów maszyn pokrytych powłokami niskotarciowymi. Wydawnictwo Naukowe Instytutu Technologii Eksploatacji - PIB, Radom 2012.

9. Pereira K., Yue T., Abdel Wahab M.: Multiscale analysis of the effect of roughness on fretting wear. Tribology International 110 (2017), pp. 222-231.

10. Szczerek M., Tuszyński W.: Badania tribologiczne. Zacieranie. Wydawnictwo Naukowe Instytutu Technologii Eksploatacji - PIB, Radom 2000.

11. Yun J.Y., Park M.C., Shin G.S., Heo J.H., Kim D.I., Kim S.J.: Effects of amplitude and frequency on the wear mode change of Inconel 690 SG tube mated SUS 409. Wear 313(2014), pp. 83-88.

12. http://www.tribologia.org/ptt-old/inst/rad/T-05.pdf. 